Dobrawa Lisak-Gębala

Instytut Filologii Polskiej, Uniwersytet Wrocławski

\title{
„Uparte trwanie baroku” w recepcji wierszy Stanisława Barańczaka
}

Ważne i nośne zjawisko w poezji polskiej (przede wszystkim tej tworzonej po 1956 roku), jakim jest powrót do dziedzictwa barokowego, przybierało różne postaci. Nie dziwi więc, że zainteresowani „upartym trwaniem baroku” [Błoński 1995] sięgają po formę pluralis - oto bowiem okazuje się, że w domenie owych jawnych wpływów (bądź li tylko domniemanych zbieżności) należy wyróżniać nie jeden „barok”, ale wiele „baroków”, indywidualnie odfiltrowanych i zreinterpretowanych przez konkretnych twórców [np. Dąbrowska 2001: 19], a także, i może nawet przede wszystkim - przez kolejnych krytyków oraz badaczy. W dyskursie metapoetyckim przywołuje się też asekuracyjnie pokrewne, trudne do jednoznacznego zdefiniowania terminy: „barokowość, „neobarok” czy „barokizowanie”.

Już w latach 6o. „barok” - rozumiany i historycznie, i ponadhistorycznie - okazał się modnym i nader pojemnym umbrella term, trochę podobnie do „postmodernizmu” po roku 1989 (zresztą te dwa terminy uznawano często za pokrewne [np. Lambert 2001]; moda na barok jest bowiem, rzecz jasna, fenomenem nie tylko polskim). Klimat kulturowy wieku XVII bywał wielokrotnie okre- 
ślany jako podobny do czasów powojennych, m.in. ze względu na rywalizowanie sprzecznych idei czy powszechność kryzysów światopoglądowych. Owe popularne diagnozy związały się też ściśle z obszarem literatury i literaturoznawstwa, a „barokowa” przygoda tych dziedzin nie obyła się bez intrygujących perypetii. Po 1956 roku, jak sugeruje Konstanty Pieńkosz [1977: 83], historyczne fascynacje samych poetów - ówczesnych debiutantów doceniających epokę dotąd traktowaną często jako "gorszą" mogły wpłynąć stymulująco na badania literatury XVII wieku; krytycy zaś zachęcali kolejnych autorów do pielęgnowania tendencji barokizujących [Eustachiewicz 1993: 12]. W dodatku pamiętać trzeba o dwóch przypadkach poetów antologistów: Jerzym S. Sicie (Poeci metafizyczni, 1981) oraz Stanisławie Barańczaku (Antologia angielskiej poezji metafizycznej XVII stulecia, 1982). Nie do przecenienia jest wpływ Jana Błońskiego, który zaistniał w podwójnej roli: krytyka literackiego zainteresowanego współczesnością oraz eksperta od literatury dawnej (książka Mikotaj Sęp Szarzyński a początki polskiego baroku, 1967). Na akuszera literackich trendów kreował się nawet znawca literatury staropolskiej, Janusz Pelc [1977: 11], zachęcający poetów, by w kolejnych latach także sięgali do niewyczerpywalnego bogactwa literatury polskiego baroku, które przypuszczalnie mogłoby okazać się inspiracją nawet w roku 2020 czy 2050. Najbardziej zapalonym propagatorem mitu baroku okazał się oczywiście Bogusław Żurakowski [1982], który dowodzil, że każda wartościowa poezja współczesna jest poezją „barokową”.

Po latach w monograficznym numerze „Znaku” zatytułowanym Dziedzictwo baroku Andrzej Borowski [1995: 6] stwierdził, iż pojęcie baroku jako „literaturoznawczy odpowiednik «Frankensteina»" nawet w badaniach historycznych okazało się chwiejne, wieloznaczne i niezbyt przydatne. Wtedy też Wojciech Bonowicz [1995: 67], próbując rozliczyć krytyków i badaczy ze zbyt śmiałego odnoszenia tego pojęcia do twórczości najnowszej, zauważył, że „wciąż trudno oddzielić to, co naprawdę «było», od tego, co tylko się «zdawało»: rzeczywiste wplywy i powinowactwa od wmówień i nieporozumień”. Według licznych analiz (publikowanych również w XXI wieku) „barokowe” tendencje patronować 
miałyby w kolejnych dekadach po roku 1956 różnorodnym przejawom twórczości poetyckiej - i tym ostentacyjnie, programowo nawiązującym do dziedzictwa dawnej epoki, jak publikowane na fali poodwilżowego zwiększenia swobody artystycznej wiersze Jerzego Harasymowicza, Stanisława Grochowiaka, Ernesta Brylla, Jarosława Marka Rymkiewicza, Jerzego Stanisława Sity, i tym mniej oczywistym, pochodzącym z różnych dekad, jak wiersze Wisławy Szymborskiej, Mirona Białoszewskiego, Czesława Miłosza czy Stanisława Barańczaka, a nawet Zbigniewa Herberta, Andrzeja Bursy, Edwarda Stachury, Tadeusza Różewicza, Rafała Wojaczka bądź Jana Twardowskiego [zob. m.in. Pelc 1977; 1993; Żurakowski 1982; Kaczmarek 1985; Lam 1992; Eustachiewicz 1993; Rowińska-Szczepaniak 1993; Delaperrière 1998; Dąbrowska 2001]. „Barokowość” współczesnej poezji może oznaczać zarówno elementy stylistyki i poetyki (np. konceptyzm bywa traktowany jako rodzaj protolingwizmu), jak i elementy szeroko ujmowanego światopoglądu (od sarmatyzmu po obsesję śmierci).

Mimo że dwukrotnie zaanonsowany został już kres epoki przemożnych wpływów dziedzictwa barokowego na poezję polską i na analizy metapoetyckie (Maria Delaperrière [1998: 11 $]^{1}$ wskazywała okres 1960-1980 jako zamknięty przedział największej wagi tego zjawiska, zaś Maria Eustachiewicz [1993: 20] stwierdziła, że po latach 70. „[t]radycja barokowa jako reguła lektury i identyfikacji kontekstu zdaje się odchodzić do lamusa historii literatury”), to w dyskursie krytycznym i literaturoznawczym omawiana tendencja wpływologiczno-komparatystyczna, co prawda w wersji przytłumionej, sporadycznie nadal daje o sobie znać, anektując obszar twórczości rozwijanej po 1989 roku, np. poezję Eugeniusza Tkaczyszyna-Dyckiego, Wojciecha Wencla, Krzysztofa Koehlera, a nawet Romana Honeta czy warszawskich neolingwistów [Hetman 2005] $]^{2}$. Jednakże warto zauważyć, że Tkaczyszyn-Dycki odżegnuje się od takich etykietek, zapewne odbieranych przezeń bardziej jako umuzealnienie niż nobilitacja [Hetman 2005: 188].

1 Wersja francuska tego tekstu opublikowana została już w 1990 roku.

2 Warto wspomnieć też obszerne katalogi młodszych „barokistów” [zob. Dąbrowska 2001: 82-91, 339; Friedrich 2016: 180]. 
Skoro mapowanie pól dyskursywnych uzależnione jest od prototypów utrwalonych w ramach folk science [Ulicka 2004: 22], to sposób mapowania poezji współczesnej w Polsce przy pomocy rozpowszechnionego prototypu „baroku” okazać się może ważkim problemem badawczym. Niniejszy artykuł ma jednak znacznie skromniejszy cel - a jest nim próba wyznaczenia punktów węzłowych w „barokizującej” recepcji wierszy jednego tylko autora: Stanisława Barańczaka.

O „barokowym” nacechowaniu wierszy Barańczaka, powstających na różnych etapach jego twórczości, pisano wielokrotnie. Jako pierwszy zwrócił uwagę na to pokrewieństwo Jerzy Kwiatkowski [1975] w szkicu z 1972 roku; na podobne transhistoryczne filiacje wskazywali w latach 70. także inni krytycy - m.in. Jacek Łukasiewicz, Tadeusz Nyczek i Krzysztof Dybciak. Ową pierwszą falę recepcji szczegółowo rejestruje Dariusz Pawelec [1992: 173 (przyp. 23)] w swojej, ukończonej w czerwcu 1990 roku, monografii, która zawiera obszerny rozdział zatytułowany Tradycja: Barok. W latach 90. dyskurs „barokizujący” dorobek autora Atlantydy zasilony został kolejnymi tekstami naukowymi. Luka w recepcji, przypadająca na lata bodaj najintensywniejszej krajowej mody na barok, wytłumaczalna jest ze względu na objęcie tekstów Barańczaka zakazem publikacji w roku 1976 [zob. Rogulska-Kołodziejska 2014: 388]. Uwagę przykuwa fakt, iż Pelc we wspomnianym już „akuszerskim” artykule Barok $\dot{z} y w y$, w jego pierwotnej, krótkiej wersji z roku 1977, nie wymieniał zaangażowanego politycznie, związanego z „drugim obiegiem” poety, natomiast w wersji rozszerzonej z 1993 roku nazwisko autora Korekty twarzy pojawiło się wielokrotnie [Pelc 1993: 324, 328, 333, 336, 337, 339]; zostało nawet zgrabnie wszyte, jako jedyny element odróżniający, do wyliczenia nazwisk we wcześniej opublikowanym zdaniu:

Jeżeli Rymkiewicz i Sito sięgają chętnie do tradycji barokowej liryki metafizycznej, do medytacji lirycznych Naborowskiego czy też Morsztynów, to tu właśnie widzą te ogniwa przeszłości, które współtworzą ich współczesną nam twórczość, które pomagają im odpowiedzieć na odwieczne pytania, czym jest człowiek, jakie są sensy jego żywota, pomagają im sformuło- 
wać takie układy słów, jakie najlepiej, najtrafniej i najpełniej zdolne są wyrazić owe myśli. [Pelc 1977: 10]

„Barokizowanie” Barańczaka w pracach publikowanych w okresie po 1989 roku może być zatem postrzegane jako efekt swoistego nadrabiania zaległości. Nasuwa się od razu, przedwczesne z pewnością, pytanie: czy ta tendencja przygasa. Porównując niektóre nowsze i dawniejsze analizy żelaznego repertuaru „barokowych” wierszy Barańczaka, można zaryzykować odpowiedź twierdzącą. Sonety łamane, według wczesnych diagnoz Pawelca, okazują się zdecydowanie „barokowe”, zaś autor Momentu lingwistycznego [Cieślak-Sokołowski 2011: 295-296] czyta je wyłącznie przez pryzmat nawiązań do kunsztownej poezji autora motta do tegoż cyklu, czyli Dylana Thomasa, idąc zresztą w ślady Ewy Rajewskiej [2007: 10]. Piotr Śliwiński [2016] analizuje wiersz [„Bo tylko ten świat bólu”], w ogóle nie używając terminu „barok”, natomiast o tym samym wierszu, sięgając po etykietkę „barokowości”, pisało wcześniej troje badaczy [zob. Pawelec 1992: 31-32; Opacka-Walasek 1995; Dąbrowska 2001: 250-251]. Trudno postawić jednoznaczną diagnozę, gdyż ważny okazuje się też profil analiz. Badanie niezwykłości formy, szczególnie w przypadku carmen figuratum, której wzorem okazują się shaped verses George'a Herberta ${ }^{3}$, oraz stylistyki często wiedzie ku „barokowym” wycieczkom komparatystycznym (choć nie bezwyjątkowo [por. np. Zawodniak 1995]).

Oczywiste jest, że „barańczakizm”, jak prześmiewczo rzecz ujął Błoński [1972: 128] w recenzji Nieufnych i zadufanych, czyli traktowanie projektu poetyckiego Barańczaka jako zamkniętego uniwersum, nie wszystko wyjaśni, zaś szukanie wpływów artystycznych i porównywanie dzieł to niezbędne składniki badań literaturoznawczych. Nie chodzi mi zatem o formułowanie pochopnych zarzutów metodologicznych, lecz o próbę bardziej zdystansowanego spojrzenia na powtarzalne procedury lekturowe w poszukiwaniu ich związków z pewnymi modami, wzorami kulturowymi. Jeśli bowiem dość powszechnie ulegamy prototypom

3 O tej tradycji w kontekście Południa pisała też Dembińska-Pawelec [1999: 101$108]$. 
podszeptywanym nam przez folk science - w kolejnych momentach historycznych otrzymujemy odmienne obrazy tego samego obiektu badań. Warto więc zapytać, jak wygląda poezja Barańczaka oglądana przez pryzmat mody na barok.

„Barokowość” w kontekście poezji Barańczaka bywała rozmaicie rozumiana. Odnoszono ją przede wszystkim do środków stylistycznych chętnie wykorzystywanych przez autora Korekty twarzy, do zasady discordia concors oraz do światopoglądu przejawiającego się w jego twórczości. Niełatwo jest rozsupłać różnorodne wątki splątane w tym „barokizującym” Barańczaka dyskursie. Sprawę komplikuje fakt, że w wielu interpretacjach wskazywanie bezpośrednich wpływów miesza się z teoriami na temat „długiego trwania” barokowej tendencji, której ewolucję obrazuje specyficznie przepisana sinusoida Krzyżanowskiego, obejmująca barok, romantyzm (przede wszystkim Norwida), awangardę międzywojenną (głównie Tadeusza Peipera wielbiącego Gongorę), starszych lingwistów i w końcu: Barańczaka jako młodszego lingwistę. Jeśli zaś bierze się pod uwagę kontekst ogólnoeuropejski - dodawana jest twórczość angielskich poetów metafizycznych, czyli realizacja baroku na wyspach brytyjskich [Wards 2011; Fabiszak 2015]. Tym tropem podąża Anton van Nieukerken [1998: 283-355] w rozdziale Stanistaw Barańczak jako wspótczesny poeta metafizyczny. Badacz na marginesie odnotowuje nazwisko jednego tylko Polaka, Mikołaja Sępa Szarzyńskiego, podkreśla natomiast stylistyczne i światopoglądowe związki Tryptyku z betonu, zmęczenia $i$ śniegu oraz Widokówki z tego świata z twórczością George'a Herberta (plain style), Johna Donne’a (specyfika konceptów), Andrew Marvella (zakorzenienie w doczesności, łączenie polityczności i metafizyczności); dodaje też kolejnych nie-XVII-wiecznych „poetów metafizycznych”, niekwestionowanych idoli Barańczaka, czyli Philipa Larkina i Thomasa.

Autor Korekty twarzy sam wprost, wręcz instruktażowo, podkreślał wymienione powyżej barokowe fascynacje - potwierdził je w rozmowach [Barańczak 1993: 27, 52, 74-75] oraz w szkicach i elementach metatekstowych towarzyszących kolejnym tomom. Odwołanie do Sępa Szarzyńskiego pojawia się wcześnie: w Nieufnych i zadufanych oraz w przedmowie do antologii (choć tu 
tylko w przypisach). Jeśli zaś chodzi o odniesienia do angielskich poetów metafizycznych, warto zwrócić uwagę na przekłady, wstęp do antologii i trzy eseje monograficzne o Donnie, Herbercie i Marvellu, publikowane w latach 1982-1985 w „Tygodniku Powszechnym" (które towarzyszyły później wyborom wierszy tych autorów), a następnie przedrukowane w Tablicy z Macondo [Barańczak 1990: 141-166]. Przypomnieć trzeba też dwa motta: cytat słów Donne’a otwierający Dziennik zimowy oraz dwuwers z Herberta otwierający tom Widokówka $z$ tego świata $i$ inne rymy $z$ lat 1986-1988 [Barańczak 2006: 225, 339].

Istotne okaże się jednak, że w wielu analizach do referowania i wyzyskiwania w interpretacji tych oczywistych wpływów literackich dochodzi także dość swobodna komparatystyka, w ramach której jako interteksty pojawiają się dzieła licznego grona poetów staropolskich, głównie tych identyfikowanych jako „konceptyści” bądź „poeci metafizyczni”. Choć Barańczak (który wszak doktoryzował się pod opieką Jerzego Ziomka) na pewno znał ich utwory, nigdy się na nich explicite nie powoływał. Przyjrzyjmy się kilku takim pracom, wprowadzającym dodatkowe powinowactwa intertekstualne.

Pawelec, u progu lat 90., przywołując afirmatywnie poglądy dwóch zwolenników uwspółcześniania baroku (i „barokizowania” współczesności): Peipera i Żurakowskiego, rozpoczyna swe analizy od inspirowanej koncepcją Ernsta Roberta Curtiusa tezy, iż barok - jako fenomen przejawiający się ponadepokowo - zyskuje liczne reprezentacje i jest wyjątkowo aktualny jako styl „manierystyczny” oraz jako powiązany ze stylem światopogląd „barokowy”. Wnikliwym analizom różnych, klasyfikowanych jako barokowe, środków (koncept, oksymoron, paradoks, antyteza, peryfraza, paronomazja) towarzyszą nawiązania do autorów, którym sam Barańczak poświęcił uwagę, czyli do wspomnianych „poetów metafizycznych” (ten termin pojawia się kilkukrotnie): Donne’a i Richarda Crashawa oraz Sępa Szarzyńskiego. Podczas omawiania związków cyklu Sonetów tamanych z debiutanckiej Korekty twarzy z 1968 roku z sonetami Sępa Szarzyńskiego pojawiają się dodatkowo odwołania do monografii Błońskiego z 1967 roku [Pawelec 1992: 33-38]. Badacz nawiązuje jednak także do innych 
autorów: Szymona Zimorowica, Jana Andrzeja Morsztyna i Sebastiana Grabowieckiego [Pawelec 1992: 11-33].

W opublikowanym dwa lata później artykule Mądry barok Barańczaka Danuta Opacka-Walasek, interpretując wiersz [„Bo tylko ten świat bólu”], zauważa wprawdzie pewne oczyszczenie poetyckiego obrazowania ze zmysłowej dosadności, zarazem podkreśla jednak „barokowe” zainteresowanie poety cielesnością i cierpieniem, a także pokrewne praktykom poetyckim dawnej epoki cechy formalne, przede wszystkim niby-żartobliwy, programowo rodzący sprzeczności koncept. Badaczka przy okazji cytuje, ocenione jako pokrewne xx-wiecznemu utworowi Barańczaka, wiersze staropolskie: Stanisława Herakliusza Lubomirskiego Pokuta w kwarantannie i Uldaryka Krzysztofa Radziwiłła Elegia jak sięświat obraca, nienawiścią lub też miłościa, i stawia tezę o występowaniu u Barańczaka „strukturalnej aluzji do liryki metafizycznej” [Opacka-Walasek 1995: 115].

Podobnym tropem podąża Joanna Dembińska-Pawelec [1999: 54-56], wykazując w kontekście analiz Tryptyku z betonu, zmęczenia $i$ śniegu związek tego tomu z barokową poezją metafizyczną, polegający na rozwijaniu podobnych tematów, takich jak przemijanie czy lęk przed śmiercią. Widokówka $z$ tego świata także okazuje się „barokowa światopoglądowo” [Dembińska-Pawelec 1999: 108-114]. I tu podkreślona zostaje ranga konceptu jako chwytu organizującego materię wierszy, zaś analizom towarzyszą cytaty z Daniela Naborowskiego i Zbigniewa Morsztyna.

Wobec powszechności odwołań do polskich „metafizyków” warto przypomnieć, że importu pojęcia poezji metafizycznej, modnego od czasu słynnej recenzji Thomasa Stearnsa Eliota [1998] z 1921 roku, dokonał Czesław Hernas w artykule Polscy poeci metafizyczni (1580-1630) z 1968 roku, w którym uwzględnił jedynie czterech autorów ze wstępnej fazy baroku (obok Sępa Szarzyńskiego byli to: Sebastian Grabowiecki, Stanisław Grochowski, Kasper Twardowski). Koniunkturę na stosowanie tej etykietki napędziły z pewnością także antologie poezji angielskiej opracowane przez Sitę i Barańczaka. Rozszerzenie chronologicznego zakresu tego pojęcia w kontekście Polski wiąże się zaś z książką Antoniego Czyża z 1988 roku o podtytule Poeci metafizyczni póź- 
nego baroku oraz z antologią pod redakcją Krzysztofa Mrowcewicza: „Wysoki umyst w dolnych rzeczach zawikłany”. Antologia polskiej poezji metafizycznej polskiego baroku. Od Mikołaja Sępa Szarzyńskiego do Stanisława Herakliusza Lubomirskiego (1993). We wstępie do wspomnianej antologii jako główni polscy „metafizycy” zostają opisani Sęp Szarzyński, Zbigniew Morsztyn i Naborowski. Takie swobodne użycie pojęcia, odnoszonego zazwyczaj do poezji angielskiej, spotkało się zresztą z ostrą krytyką Andrzeja Litworni [1996]. Termin „poezja metafizyczna”, podobnie jak „barok”, okazuje się zatem rodzajem umbrella term, lansowanym na fali tej samej mody intelektualnej. Jasna staje się w tym kontekście przyczyna posługiwania się przez badaczy poezji Barańczaka inkluzywnym, szerokim pojęciem liryki metafizycznej (choć nadal używane jest jako kwalifikacja historycznoliteracka odnoszona do baroku polskiego, bo funkcjonuje ono przecież także ponadhistorycznie).

Niezbędną pozycją w tym chronologicznym przeglądzie jest przekrojowa monografia Elżbiety Dąbrowskiej [2001] Teksty w ruchu. Powroty baroku w polskiej poezji wspótczesnej. Barańczak, pojawiający się tu w towarzystwie Miłosza i Szymborskiej, zdecydowanie różni się od poetów jawnie nawiązujących do baroku sarmackiego (Rymkiewicz, Bryll, Grochowiak, Harasymowicz), których badaczka wymienia w pierwszej kolejności. Dąbrowska oczywiście niuansuje swoje interpretacje, wyszczególniając różne wymiary neobaroku. W przypadku twórczości Barańczaka wskazuje głównie na bardzo swoistą, nieteocentryczną wersję poezji metafizycznej, oraz na tendencję do rozwijania „harmonii dysonansów” [Dąbrowska 2001: 250-272]. Inni patroni pojawiają się też w kontekście konkretnych autorów, u wcześniej wspomnianych czterech miłośników sarmackości: Wacław Potocki, Zbigniew Morsztyn, Józef Baka, zaś u Barańczaka przede wszystkim Sęp Szarzyński i Donne, a także inni angielscy „metafizycy”: Marvell i Herbert; Dąbrowska [2001: 250] wymienia też Naborowskiego, Morsztyna, Grabowieckiego oraz Bakę. Ten ostatni zostaje wspomniany w kontekście omawiania Dialogu Duszy i Ciała (z Chirurgicznej precyzji), będącego prześmiewczym przetworzeniem tak samo zatytułowanego utworu Marvella; opatrzono go znamienną dedykacją: „Cieniom Andrew Marvella i, na wszelki wypadek, 
także Xiędza Józefa Baki” [Barańczak 2006: 451]. Ponownie więc mamy do czynienia z sytuacją, w której twórczość licznych autorów polskiego baroku pojawia się raczej „na wszelki wypadek” - właśnie jak w cytowanej dedykacji. Skojarzenie z Baką jest swoistym novum w recepcji poezji Barańczaka, novum sprowokowanym oczywiście dedykacją Dialogu... Dąbrowska dowodzi przekonująco, że od Baki pochodzi wzór formy „siekańca”. Warto jednak zauważyć, że, po pierwsze, w tym żartobliwym wierszu zostają przemieszane wątki nawiązujące do wielu epok i kręgów kulturowych (np. fraza „Dusza z ciała wyleciała” to przytoczenie średniowiecznego anonimowego tekstu; przywołany jest i Dumasowski Hrabia Monte Christo), więc „barokowość” à la Baka byłaby tylko jedną warstwą intertekstualnego palimpsestu. Po wtóre, podczas gdy odwołanie do spuścizny Marvella sugeruje wagę poruszanych kwestii metafizycznych, wzmianka o Bace stanowić może istotny sygnał komizmu. Recenzując tomik Harasymowicza z 1979 roku i doceniając żarty czerpiące z dorobku XVIII-wiecznego jezuity, Barańczak [1988: 49] bezpardonowo skwitował wszak rangę autora Uwag śmierci niechybnej:

[...] sarmacka metafizyka (każdy naród ma takich „poetów metafizycznych", na jakich go stać...), rymująca bezustannie „ducha” z „brzuchem”, łącząca w sobie patos spraw ostatecznych z rubaszną, cielesną przyziemnością.

Podsumowując ten krótki przegląd, warto zauważyć, że praktyka badaczy, polegająca na przywoływaniu „na wszelki wypadek” wielu polskich poetów barokowych, szczególnie tych niewymienianych przez Barańczaka w galerii patronów twórczości, wpływa pośrednio na spektrum wątków, które odtąd spowinowacają się z poezją współczesnego autora. Konceptyzm Barańczaka często uznaje się za typowo „barokowy”, co pociąga za sobą wskazywanie podobieństw do kolejnych potencjalnych intertekstów - a te zagarniają też obszar tematów i idei. Co prawda, sam poeta dał asumpt do łączenia formy ze światopoglądem - przykładowo w cytowanej wyżej recenzji stwierdził: „Pożyczanie od kogoś stylu jest jednak prawie zawsze transakcją wiązaną: choćby się 
tego nie chciało, w tkankę wierszy przenikają zarazem i elementy światopoglądu wierzyciela” [Barańczak 1988: 49]. Maria Eustachiewicz [1993: 38] doradzała jednak ostrożność przy takich zakusach transhistorycznego utożsamiania, sugerując, iż pewne figury i tendencje, uważane za typowo „barokowe”, jak paradoksalność czy antytetyczność, „mogą być także zupełnie innej proweniencji”.

Ważnym tropem w tym kontekście może się okazać np. petrarkizm czy Peiperowski „układ rozkwitania”. Podobnie „innej proweniencji” może być np. motyw vanitas. Stąd z jednej strony rodzi się pytanie: czy konceptyzm Barańczaka, jeśli już ma być wywodzony z konkretnych XVI- i XVII-wiecznych tradycji, nie powinien być jednak traktowany bardziej ekskluzywnie - kojarzony z krótką listą antenatów-„,metafizyków” (teorię konceptu wyłożył wszak szczegółowo i afirmatywnie właśnie we wstępie do antologii), a nie rozszerzony do dziedzictwa całej wewnętrznie zróżnicowanej formacji barokowej. Z drugiej strony budzi się wątpliwość z gruntu odmienna od powyższego pytania: czy sam Barańczak dążył do tego, by swe sympatie poetyckie zamykać w jednej tylko epoce? Nieraz przecież postrzegał kwestie literackie zdecydowanie ponadepokowo, np. „[...] wertykalny układ przestrzenny, w którym dusza ludzka wznosi się ku Bogu, należy [...] do zasobu loci communes liryki religijnej wszystkich epok i języków” [Barańczak, oprac. 2009: 22]. Obydwa zastrzeżenia zbiegają się w pytaniu o to, komu bardziej zależy na etykietce „barokowości” patronującej twórczości Barańczaka - samemu poecie czy komentatorom.

Nie można wszakże pominąć kwestii związku wczesnych „barokowych” fascynacji samego Barańczaka, poety i naukowca, $\mathrm{z}$ ówczesną modą literaturoznawczą. Autorytetem dla niego okazała się z pewnością przywołana w Nieufnych i zadufanych oraz we wstępie do antologii Jadwiga Sokołowska [1971; 1978]. Nietrudno też domyślić się, skąd u młodego studenta polonistyki zainteresowanie Sępem Szarzyńskim, którego, co istotne, nie uwzględniała, zapewne z przyczyn chronologicznych [Balbus 2002: 20], antologia z 1965 roku Poeci polskiego baroku. W 1967 roku ukazała się niezwykle wpływowa praca Błońskiego o Sępie Szarzyńskim 
(w tytule przywołująca termin „barok”), która, jak przekonują liczni interpretatorzy [Pieńkosz 1977: 72; Eustachiewicz 1993: 8; Pelc 1993: 311; Balbus 2002: 20-21; Borowski 2002: 14-16; Nasiłowska 2010], z polskiego baroku, będącego dotąd tematem dla szperaczy bibliotecznych i tworem uważanym za dekadencki, uczyniła wyjątkowo atrakcyjną dla XX-wiecznych czytelników formację kulturalną. Barańczak zacytuje tę monografię już w 1971 roku w Nieufnych i zadufanych, „genialny kształt językowy” wierszy Sępa Szarzyńskiego i jego światopogląd traktując jako pars pro toto baroku, mającego być wcześniejszą wersją „,romantyzmu dialektycznego". Poeta zachwyca się tu barokową przerzutnią która rodzi kolizje i pociąga, jak pisze, „daleko idące implikacje światopoglądowe” [Barańczak 1971: 25]; w przypisie zaś dodaje: „Wnikliwe obserwacje na ten temat zawarł J. Błoński w cytowanej książce o Szarzyńskim”.

Swoją drogą, odpowiedzialne za „złamanie” sześciu młodzieńczych sonetów Barańczaka są właśnie przerzutnie, także te między strofami. Analogii między tezami Błońskiego a programem Barańczaka można znaleźć sporo. Będąca wyrazem dialektyki oksymoroniczność ma się wszak przejawiać już w warstwie brzmieniowej: $w$ instrumentacji głoskowej, rytmie, intonacji [Barańczak 1971: 24-25] - to elementy, które krakowski badacz analizował w rozdziale Retoryka paradoksu [Błoński 2001: 98-130]. Barańczak do monografii o Sępie Szarzyńskim odniesie się także w referacie na temat angielskiej poezji metafizycznej, wygłoszonym w 1979 roku podczas konferencji Sacrum $w$ literaturze organizowanej przez KUL, dołączonym potem jako przedmowa do antologii z 1982 roku. W szkicu tym Barańczak wskazuje na pokrewieństwa w zakresie „barokowego” właśnie światopoglądu między Donne'em i jego naśladowcami oraz polskim poetą. O tym pokrewieństwie pisał zresztą Błoński [2001: 133, 139], który notabene nie wymienił $\mathrm{z}$ nazwiska któregokolwiek innego angielskiego poety metafizycznego. Jako wspólne elementy badacz wskazał wówczas „paradoksalną metaforykę”, która ma „objąć sprzeczności ludzkiego doświadczenia”, „poetykę szoku”, „intelektualnego skandalu”, „niezborność obrazu i znaczenia”. Skoro nie tylko esej z Nieufnych izadufanych, ale także - jak przekonywał niedawno Andrzej 
Skrendo [2014: 303-304 (przyp. 56)] - przedmowę do antologii traktować należy jako teksty programowe (definicja poezji metafizycznej to właściwie wyłożona innymi słowami teoria „romantyzmu dialektycznego”), to okazuje się, że Barańczak sam jawnie się za barokiem opowiedział. Szkic Człowiek Donne'a zapewne też uznać można za „programowy” [Nieukerken 1998: 286]. Jest to jednak barok traktowany dość wąsko - jeśli chodzi o szczupłe grono faktycznych idoli, a także o wybór pewnej wersji konceptyzmu („swoiście racjonalnego”, przeintelektualizowanego, a nie wybujałego i zmysłowego) oraz światopoglądu wiązanego z konceptyzmem „metafizyków”. Lecz przy zmianie optyki ów barok okaże się ujęty dość szeroko, bo przekracza wąskie ramy chronologiczne, stając się powracającą co pewien czas u różnych autorów metodą poezjowania. „Stronniczość i wyjaskrawienie nie mówiąc o nadużyciu terminów i fałszowaniu genealogii - jest przywilejem twórców programów” - tak oto, zarazem bezlitośnie i wyrozumiale, sam Błoński [1972: 131] podsumował program Barańczaka z roku 1971.

Na zakończenie trzeba też zastanowić się nad fortunnością przywoływania terminu „barok” w odniesieniu do wierszy Barańczaka w kontekście dwóch jeszcze kwestii. Primo, barok wybierany przez autora Nieufnych i zadufanych to barok rodem z wysp brytyjskich, czyli bez rysu katolickiej kontrreformacji (Barańczak papistą Crashawem interesuje się jakby mniej...); w dodatku termin „barok” w angielskim dyskursie literaturoznawczym praktycznie nie funkcjonuje [Wards 2011; Fabiszak 2015], a pojawienie się tego słowa, np. we wstępie do antologii, jest wkładem Barańczaka oswajającego obce realia kulturowe. Secundo, „barok” Barańczaka powiązany jest w dużej mierze z poetą międzyepoki: Sępem Szarzyńskim. Zresztą i Donne, o pokolenie starszy od swoich następców, okazuje się według autora Tablicy z Macondo zawieszony pomiędzy nurtami:

[...] renesansowa hierarchia świata wyznacza u Donne’a granice i materiał wyobraźni; nie przeszkadza to jednak nowym, barokowym niepokojom i rozterkom wprawiać składniki tego świata w dramatyczny ruch. [Barańczak 1990: 147] 
Przypomnijmy, iż Błoński określił Sępa Szarzyńskiego jako poetę manieryzmu, którego styl miałby być „poetyką baroku w materiale renesansu" (notabene został uwzględniony w syntezie renesansu Ziomka [1995], który odnotował jego związek z manieryzmem, zaś w Baroku Hernasa [1998] widnieje w dziale Wczesny barok). U obydwu dostrzegają interpretatorzy pewien chłód intelektualny, związki ze sztuką medytacji, przefilozofowany, ignacjański z ducha charakter konceptów - daleki od zmysłowości i powierzchowności dojrzałego baroku [Mrowcewicz 1993: 11-16, 25-26, 29-32; Błoński 2001: 48-50, 145-163]. Odmienność tak rozumianego wczesnego baroku warto wziąć pod uwagę w odniesieniu do wierszy Barańczaka. Emblematyczność, brak zmysłowej dosłowności obrazowania, rygor, logika - to wszak cechy, które często omawiają interpretatorzy jego poezji [np. Opacka-Walasek 1995].

Odnosząc się do niejednoznacznej przynależności Sępa Szarzyńskiego do prądów literackich, Błoński [2001: 230] tak oto wieńczył swoje rozważania w Przypisku zupetnie nienaukowym: „Nie ufajmy naklejkom, wierzmy ludziom i dziełom, które nas wzruszają i współtworzą”. Z kolei Borowski [2002: 15] podkreślał wielką wagę tego apelu:

Jan Błoński zrujnował ówcześnie kanoniczny, kontrastowy naiwnie czarno-biały, bo zideologizowany obraz tzw. procesu historycznoliterackiego, w którym pieczątkami z napisem „renesans” i „barok” posługiwano się z wdziękiem i skutecznością zaspanego urzędnika celnego.

Nauka, także nauka o literaturze, jak wiadomo, z trudem obywa się bez naklejek i pieczątek, ale warto zapytać, czy Barańczak nie nawinął się kilkukrotnie - może nieco hurtem i „na wszelki wypadek” - pod rękę poszukiwaczom kolejnych egzemplifikacji tezy o neobarokowości polskiej poezji współczesnej. Zapewne nie wszystkie odciski stempla mu się należały. Na takie praktyki literaturoznawcze wpłynęła zapewne powszechna fascynacja barokiem, której sam poeta po części uległ. Bardzo wcześnie zorientował się, że barok już w latach 6o. stał się „wyraźnie modny”; przytomnie, i może nawet nieco profetycznie, doprecyzowywał jednak: 
w mniejszym stopniu u poetów (tylko „w mottach i powierzchownych stylizacjach”), w większym - w historii literatury i w krytyce literackiej [Barańczak 1971: 13].

\section{Bibliografia}

Balbus Stanisław (2002), Błoński krytyk - Błoński uczony, w: Jan Błoński ... i literatura XX wieku, red. Małgorzata Sugiera, Ryszard Nycz, Universitas, Kraków, s. 17-33.

Barańczak Stanisław (1971), Nieufni i zadufani. Romantyzm i klasycyzm $w$ mtodej poezji lat sześćdziesiątych, Ossolineum, WrocławWarszawa-Kraków-Gdańsk.

Barańczak Stanisław (1988), Przed i po. Szkice o poezji krajowej przełomu lat siedemdziesiatych i osiemdziesiatych, Aneks, Londyn [Wielka Brytania].

Barańczak Stanisław (1990), Tablica z Macondo. Osiemnaście prób wyttumaczenia, po co i dlaczego się pisze, Aneks, Londyn [Wielka Brytania].

Barańczak Stanisław (1993), Zaufać nieufności. Osiem rozmów o sensie poezji, red. Krzysztof Biedrzycki, M, Kraków.

Barańczak Stanisław (2006), Wiersze zebrane, a5, Kraków.

Barańczak Stanisław, wybór, wstęp, przeł., oprac. (2009), Antologia angielskiej poezji metafizycznej XVII stulecia, a5, Kraków.

Błoński Jan (1972), Podpalenie Arkadii, „Teksty”, nr 2, s. 122-131.

Błoński Jan (1995), Uparte trwanie baroku, „Znak”, nr 7, s. 69-75.

Błoński Jan (2001), Mikołaj Sęp Szarzyński a początki polskiego baroku, wyd. 2 popr., Universitas, Kraków.

Bonowicz Wojciech (1995), Tradycja oczywista? Kilka uwag o recepcji baroku w polskiej poezji wspótczesnej, „Znak”, nr 7, s. 67-84.

Borowski Andrzej (1995), Co nam dzisiaj po baroku?, „Znak”, nr 7, s. 4-9.

Borowski Andrzej (2002), Nowoczesny Sarmata, w: Jan Błoński ... i literatura XX wieku, red. Małgorzata Sugiera, Ryszard Nycz, Universitas, Kraków, s. 9-16.

Cieślak-Sokołowski Tomasz (2011), Moment lingwistyczny. O wczesnej poezji Ryszarda Krynickiego i Stanistawa Barańczaka, Universitas, Kraków.

Czyż Antoni (1988), Ja i Bóg. Poezja metafizyczna późnego baroku, Ossolineum, Wrocław-Warszawa-Kraków-Gdańsk-Łódź.

Dąbrowska Elżbieta (2001), Teksty w ruchu. Powroty baroku w polskiej poezji wspótczesnej, Wydawnictwo Uniwersytetu Opolskiego, Opole. 
Delaperrière Maria (1998), Dialog z tradycją, Universitas, Kraków.

Dembińska-Pawelec Joanna (1999), Światy możliwe w poezji Stanistawa Barańczaka, Wydawnictwo Uniwersytetu Śląskiego, Katowice.

Eliot Thomas Stearns (1998), Poeci metafizyczni, przeł. Maciej Żurowski, w: tegoż, Kto to jest klasyk i inne eseje, Znak, Kraków, s. 130-141.

Eustachiewicz Maria (1993), Z recepcji baroku w poezji polskiej po r. 1956, w: Z badań nad polska tradycją literacka, red. Jacek Łukasiewicz, Wiedza o Kulturze, Wrocław, s. 7-63.

Fabiszak Jacek (2015), Stanisław Barańczak: barok a sprawa angielska, $\mathrm{w}$ : „To życie tylko cieniem jest przelotnym...”. Pamięci Stanisława Barańczaka, Wydawnictwo UwM, Olsztyn, s. 13-22.

Friedrich Michał (2016), Barok w poezji Jerzego Harasymowicza. Interpretacje, konteksty, powinowactwa, Wydawnictwo Polonistyki Uniwersytetu Warszawskiego, Warszawa.

Hernas Czesław (1968), Polscy poeci metafizyczni (1580-1630), „Prace Literackie", t. 10, s. 23-53.

Hernas Czesław (1998), Barok, PwN, Warszawa.

Hetman Grzegorz (2005), Twórczość polskich poetów debiutujących po 1989 r. w kręgu barokowych inspiracji i odniesien. Wybrane problemy, „Prace Literackie”, t. 45, s. 171-188.

Kaczmarek Marian (1985), Od anatemy do fascynacji, czyli o żywej obecności sarmackiego baroku w literaturze wspótczesnej, w: Barok i barokowość w literaturze polskiej, red. Marian Kaczmarek, Wyższa Szkoła Pedagogiczna w Opolu, Opole, s. 91-105.

Kwiatkowski Jerzy (1975), Stowo Barańczaka, w: tegoż, Notatki o poezji i krytyce, Wydawnictwo Literackie, Kraków, s. 107-111.

Lam Andrzej (1992), Echa baroku w poezji Wistawy Szymborskiej, w: Barok w polskiej kulturze, literaturze i języku, red. Marian Stępień i Stanisław Urbańczyk, PwN, Kraków, s. 115-120.

Lambert Gregg (2001), On the (new) baroque, The Davies Group Publishers, Aurora [USA].

Litwornia Andrzej (1996), „Wysoki umyst w dolnych rzeczach zawikłany” [recenzja], „Pamiętnik Literacki”, z. 1, s. 218-224.

Mrowcewicz Krzysztof (1993), Wstęp, w: „Wysoki umyst w dolnych rzeczach zawikłany". Antologia polskiej poezji metafizycznej polskiego baroku. Od Mikołaja Sępa Szarzyńskiego do Stanisława Herakliusza Lubomirskiego, oprac. Krzysztof Mrowcewicz, Wydawnictwo IBL PAN, Warszawa, s. 7-43.

Nasiłowska Anna (2010), Barok narodowy, „Kwartalnik Artystyczny”, nr 1, s. 137-139. 
Nieukerken Anton van (1998), Ironiczny konceptyzm. Nowoczesna polska poezja metafizyczna, Universitas, Kraków.

Opacka-Walasek Danuta (1995), Mądry barok Barańczaka, „Opcje”, nr 1-2, s. 111-116.

Pawelec Dariusz (1992), Poezja Stanisława Barańczaka. Reguly i konteksty, Wydawnictwo Śląsk, Katowice.

Pelc Janusz (1977), Barok a nasza wspótczesność, „Poezja”, nr 5-6, s. 3-15.

Pelc Janusz (1993), Barok - epoka przeciwieństw, Czytelnik, Warszawa.

Pieńkosz Konstanty (1977), Barok i liturgia słowa we wspótczesnej poezji polskiej, „Poezja”, nr 12, s. 72-83.

Rajewska Ewa (2007), Stanisław Barańczak - poeta i tłumacz, Wydawnictwo Poznańskie, Poznań.

Rogulska-Kołodziejska Agnieszka (2014), Przypadek Stanisława Barańczaka, w: Kariera pisarza w PRL-u, red. Magdalena Budnik i in., Wydawnictwo IBL PAN, Warszawa, s. 387-408.

Rowińska-Szczepaniak Maria (1993), Zainteresowanie barokiem wśród wspótczesnych poetów polskich, w: $W$ kręgach baroku i barokowości. Studia, red. Marian Kaczmarek, Wyższa Szkoła Pedagogiczna w Opolu, Opole, s. 177-196.

Sito Jerzy Stanisław, oprac. (1981), Poeci metafizyczni, PAx, Warszawa. Skrendo Andrzej (2014), Stanistaw Barańczak - widma poezji, „Teksty Drugie", nr 2, s. 284-306.

Sokołowska Jadwiga, Żukowska Kazimiera, oprac. (1965), Poeci polskiego baroku, t. 1-2, PIW, Warszawa.

Sokołowska Jadwiga (1971), Spory o Barok. W poszukiwaniu modelu epoki, PIw, Warszawa.

Sokołowska Jadwiga (1978), Dwie nieskończoności. Szkice o literaturze barokowej Europy, PIw, Warszawa.

Śliwiński Piotr (2016), Kartografia ziemskiego bólu. Stanisław Barańczak „Bo tylko ten świat bólu”, „Przestrzenie Teorii”, nr 26, s. 139-148.

Ulicka Danuta (2004), Narracyjna i nienarracyjna koncepcja dyskursu literaturoznawczego, „Przestrzenie Teorii”, nr 3-4, s. 21-42.

Wards Jean (2011), „Czosnek w btocie”. Termin „barok” a poezja angielska, „Pamiętnik Literacki”, z. 4, s. 81-97.

Zawodniak Mariusz (1995), Świetna zabawa: uwagi o kompozycji „Widokówki z tego świata” Stanisława Barańczaka, „Teksty Drugie”, $\mathrm{nr} 2$, s. 148-162.

Ziomek Jerzy (1995), Renesans, PWN, Warszawa.

Żurakowski Bogusław (1982), Paradoks poezji, Wydawnictwo Literackie, Kraków. 
Dobrawa Lisak-Gębala

'The Stubborn Persistence of the Baroque' in the receptions of Stanisław Barańczak's poems

The article focuses on the functioning of the term 'baroque' in the reception of Stanisław Barańczak's poems. The author takes into account the context of fashion for returning to the legacy of the baroque which became visible after 1956 in both poetry itself and in the discourse of both literary criticism and literary studies.

Keywords: Barańczak Stanisław - reception; baroque; Polish 2oth-century poetry; Polish 21st-century poetry; metaphysical poetry; Polish literary history; analysis of literary studies discourse.

Dobrawa Lisak-Gębala - doktor, z wykształcenia polonistka i kulturoznawczyni. Autorka dwóch monografii: Ultraliteratura (2014) i Wizualne odskocznie (2016), współredaktorka tomów: Esej - sztuka - nauka (2011), Czytając Czapskiego (2015), Centra - peryferie w literaturze polskiej XX i XXI wieku (2015), oraz numeru czasopisma „Res Facta Nova” (2016, nr 17). Artykuły naukowe publikowała m.in. w „Zagadnieniach Rodzajów Literackich”, „Pamiętniku Literackim”, „Przestrzeniach Teorii”, „Czytaniu Literatury” i „Autobiografii”. Interesuje się historią literatury polskiej Xx i XXI wieku oraz związkami literatury współczesnej z innymi dziedzinami sztuki. Adres e-mail: dobrawa.lisak-gebala@uwr.edu.pl. 